\title{
Contaminant Biotransport by Pacific Salmon in the Great Lakes
}

\author{
Brandon S. Gerig ${ }^{1 *}$, David J. Janetski ${ }^{2}$, Dominic T. Chaloner ${ }^{3}$ and Gary A. Lamberti ${ }^{3}$ \\ ${ }^{1}$ Department of Biology, Northern Michigan University, Marquette, MI, United States, ${ }^{2}$ Department of Biology, Indiana \\ University of Pennsylvania, Indiana, PA, United States, ${ }^{3}$ Department of Biological Sciences, University of Notre Dame, \\ Notre Dame, IN, United States
}

OPEN ACCESS

Edited by:

Jules Blais,

University of Ottawa, Canada

Reviewed by:

Luis Schiesari,

University of São Paulo, Brazi

Kathryn Hargan,

Memorial University of Newfoundland,

Canada

*Correspondence:

Brandon S. Gerig

bgerig@nmu.edu

Specialty section:

This article was submitted to

Population and Evolutionary

Dynamics,

a section of the journal

Frontiers in Ecology and Evolution

Received: 30 August 2019

Accepted: 02 June 2020

Published: 24 June 2020

Citation:

Gerig BS, Janetski DJ,

Chaloner DT and Lamberti GA (2020)

Contaminant Biotransport by Pacific

Salmon in the Great Lakes.

Front. Ecol. Evol. 8:199.

doi: 10.3389/fevo.2020.00199
In the Laurentian Great Lakes, introduced Pacific salmon (Oncorhynchus spp.) deposit resources and contaminants as carcass and gametic tissue during spawning migrations to tributaries. Such ecosystem linkages can increase growth and contaminant bioaccumulation in stream-resident fish but mechanisms driving this process remain unclear. In this mini-review, we synthesize findings from observational, experimental, and modeling studies related to Pacific salmon contaminant biotransport in the Great Lakes. First, contaminant biotransport varies among Great Lakes basins suggesting that basin-level characteristics including salmon abundance and historic contamination are important factors controlling the movement of contaminants from the lakes to tributaries. Second, stream-resident fish exposed to salmon have 24-fold higher PCB but moderately lower $\mathrm{Hg}$ concentrations when compared to locations without salmon. This finding is explained by differential bioaccumulation of PCB and Hg into different tissue types; analysis of salmon tissue indicates that eggs have elevated PCB and lower Hg than carcasses. Third, stream-resident fish exhibit a dietary shift and increased ration reflecting salmon egg consumption. Last, models suggest that salmon egg consumption can drive a trade-off between PCB and Hg bioaccumulation. This review identifies mechanisms controlling the transfer of salmon-derived energy potential strategies for management. Future research should be directed at identifying other biovectors and determining a list of emerging contaminants that could be subject to biotransport.

Keywords: Pacific salmon, contaminant biotransport, bioaccumulation, resource subsidy, ecosystem linkage

\section{MECHANISMS OF CONTAMINANT DISPERSAL}

Pollution is one of five global drivers of environmental change that contributes to biodiversity loss and human health impairment (Assessment, 2005). Contaminants including persistent organic pollutants (POPs), heavy metals, and emerging contaminants including per- and polyfluoroalkyl substances (PFAS), pharmaceuticals, and microplastics are a concern to organisms, ecosystems, and human health (Murphy et al., 2012). Although environmental concentrations of some POPs (e.g., PCBs [polychlorinated biphenyls], DDE [1,1-dichloro-2,2-bis[p-chlorophenyl] ethylene], PBDEs [polybrominated diphenyl ethers]) have declined due to environmental regulations in the United States and later internationally under the Stockholm Convention, concentrations in fish remain high enough to warrant sport fish consumption advisories and to elicit concern over effects on piscivorous wildlife (Murphy et al., 2012). Risks to humans and wildlife persist due to 
the resistance of these pollutants to degradation coupled with their ability to bioaccumulate and biomagnify in food webs (Clements et al., 2012). The impact of contaminants can be magnified when contaminants are moved between disconnected ecosystems.

Understanding the movement of contaminants requires characterization of physical, chemical, and biological processes which dictate contaminant fate in the environment. Transport of contaminants has largely been described through mechanistic models of contaminant volatilization, deposition, and uptake dynamics (Mackay and Fraser, 2000). These models are useful for raising awareness of the risk and consequences of longrange contaminant transport to human populations, such as indigenous human populations in the Arctic (Blais, 2005). However, the biological aspects of contaminant transport in these models can be overly simplistic. For instance, bioaccumulation models often make predictions that inadequately describe an organism's lifetime consumption and growth, which strongly influences overall contaminant burden and concentration. In addition, they often fail to use site-specific environmental, diet, and contaminant data (Schiesari et al., 2018). Moreover, most models do not include biological processes, such as animal migrations that disperse contaminants across ecosystem boundaries (Kallenborn and Blais, 2015).

Conventional models of contaminant transport do not include biological transport of contaminants across ecosystem boundaries (Schiesari et al., 2018). Animal migrations are responsible for the mass transport of nutrients and energy (Bauer and Hoye, 2014). Indeed, these often predictable pulses of energy from migratory organisms strongly influence multiple trophic levels in the ecosystem receiving the subsidy (Polis et al., 2004; Lamberti et al., 2010), modulating ecosystem stability and community biodiversity (Bauer and Hoye, 2014). Relative to the subsidy effects, the process and broader impacts of contaminant biotransport remain poorly understood (Schiesari et al., 2018). Migratory organisms can accumulate and disperse large contaminant loads, but the mechanisms driving the spatial patterns and rates of bioaccumulation of biologically transported contaminants have not yet been synthesized. With this mini-review, we will describe the process of contaminant biotransport, using Pacific salmon in the Laurentian Great Lakes as a case-study to describe factors controlling contaminant biotransport. The Laurentian Great Lakes are useful for this task because of the large amount of information that has been generated on contaminants, including their biotransport (Janetski et al., 2012; Murphy et al., 2012; Gerig et al., 2018), while being a globally important freshwater resource (Bunnell et al., 2014).

\section{BIOLOGICAL TRANSPORT OF CONTAMINANTS}

Contaminant biotransport is the dispersal of contaminants by organisms via movement within or among systems. The process of contaminant biotransport is characterized by several steps including: (1) contaminant bioaccumulation by a migratory organism; (2) contaminant transport across an ecosystem boundary; and (3) contaminant deposition into the recipient ecosystem (Blais et al., 2007; Kallenborn and Blais, 2015). This process can include a fourth step related to variables that control how biotransported contaminants are accumulated in the recipient food web (Gerig et al., 2018). Furthermore, life history traits of the biovector including breeding strategy (e.g., semelparity), large size, high trophic position, increased fecundity, and synchronicity of movement enhance the likelihood an organism will biologically transport contaminants (Janetski et al., 2012; Schiesari et al., 2018). Both migratory fish and colonial nesting sea birds are prominent examples of contaminant biovectors due to their contaminant burdens, movement patterns and ability to liberate contaminants into a new ecosystem (Krümmel et al., 2003; Michuelleti et al., 2010). Examples of contaminant biotransport run counter to the more usual unidirectional flow of material, such as with flowing water or eroding soils, or from land to sea, thereby facilitating a connection between areas without contaminants and those areas replete with contaminants. Moreover, biovectors accumulate contaminants over a broad spatial area and focus them into a much smaller area. For example, Pacific salmon introduced to the Great Lakes accumulate contaminants from across an entire lake basin prior to migrating to streams to spawn, thereby focusing their contaminant burden into a small area.

The introduction of Pacific salmon (Oncorhynchus spp.) to the Laurentian Great Lakes in the mid-1960s provides a valuable setting to evaluate the role of contaminant biotransport. Pacific salmon were introduced to control alewife (Alosa pseudoharengus) and establish a sport fishery (Crawford, 2001; Dettmers et al., 2012). However, establishment of salmon coincided with peak levels of many POPs, which bioaccumulate in aquatic food webs and have negative consequences for fish, wildlife, and human health (Murphy et al., 2012). In the 60 years since salmon were stocked, salmon have become naturalized to many streams and exhibit natural recruitment (Dettmers et al., 2012). As a consequence, many Great Lakes tributaries have annual runs of Pacific salmon that facilitate the translocation of contaminants from lake to tributary (Figure 1). Thus, migratory salmon can be considered a source of contaminants to tributaries of the Great Lakes region, now and in the future (Janetski et al., 2012; Gerig et al., 2018).

\section{CONTAMINANT BIOTRANSPORT IN THE LAURENTIAN GREAT LAKES}

Research from the Great Lakes over the last decade has increased our understanding of contaminant biotransport by Pacific salmon. We now appreciate that stream-resident fish can acquire contaminants from salmon spawners (Janetski et al., 2012; Gerig et al., 2018). Moreover, the primary mechanism by which salmon facilitate contaminant dispersal and bioaccumulation is through their eggs, which are consumed readily by streamresident fish (Gerig et al., 2019). Thus, salmon create a direct linkage between the Great Lakes and a vast tributary network facilitating the translocation of contaminants to locations often 


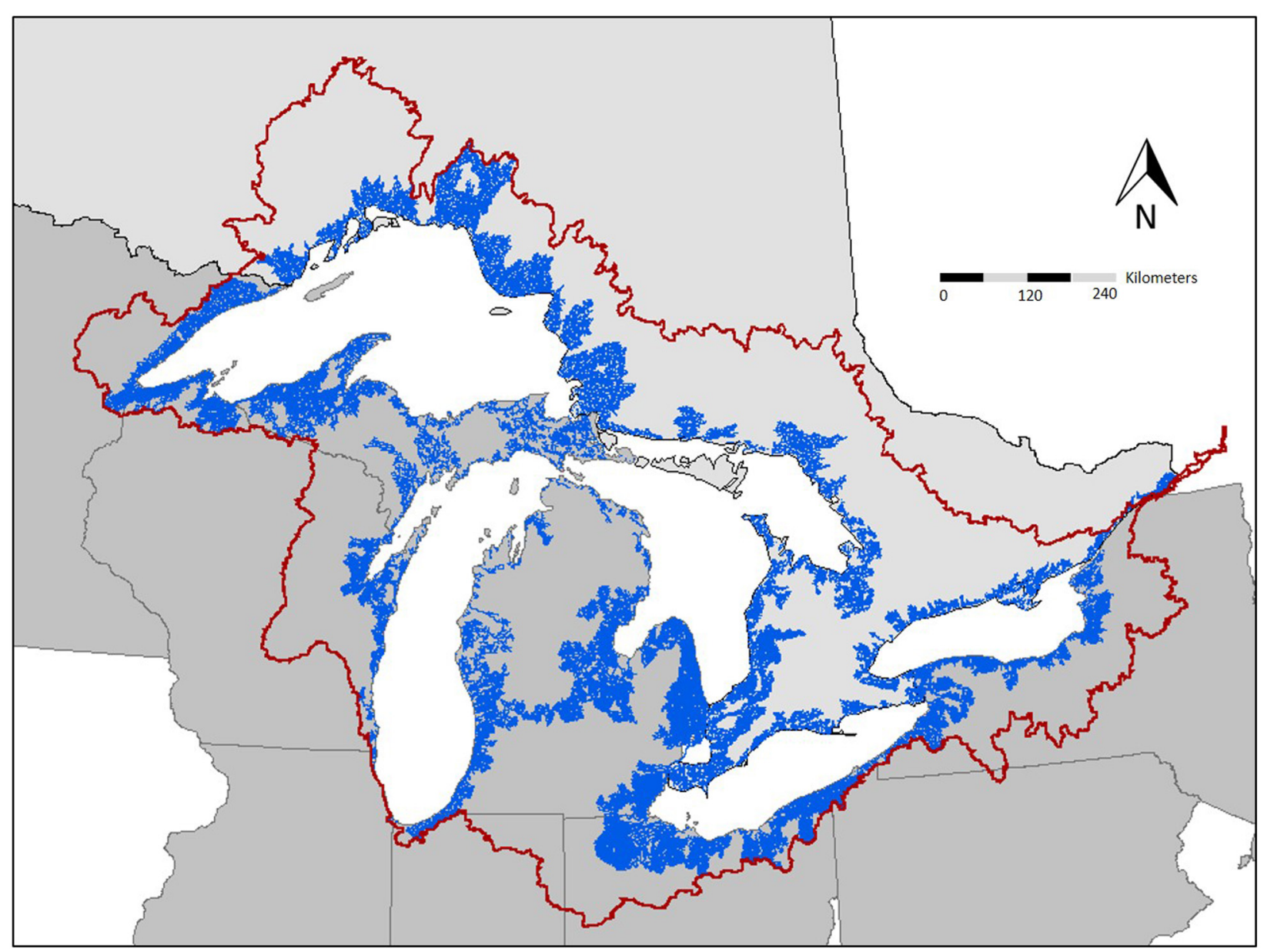

FIGURE 1 | Potential extent of contaminant biotransport in the Great Lakes basin. The dark red line represents the Great Lakes watershed boundary. The blue lines represent tributaries that are accessible to migratory fish. Tributary accessibility data obtained through open source data acquired through Great Lakes aquatic habitat framework.

lacking direct point sources of contamination (Janetski et al., 2012; Gerig et al., 2018).

Prior studies suggest the quantity of a contaminant deposited to a stream is strongly influenced by two factors - the contaminant burden and the abundance of the salmon. That relationship can be summarized in the following equation:

$$
\begin{aligned}
& \text { Contaminant flux }\left(\mathrm{ng} \mathrm{m}^{-2}\right) \\
& =\text { Mean contaminant load of biovector }(\mathrm{ng}) \\
& \left.\quad \times \text { Abundance per unit habitat area }\left(\mathrm{N} \mathrm{m}^{-2}\right)\right]
\end{aligned}
$$

The quantity of contaminants delivered by salmon can increase either as a function of highly contaminated individuals migrating at low densities, less contaminated individuals migrating at high densities (Krümmel et al., 2003), or the interaction of both (Janetski et al., 2012; Gerig et al., 2018). This relationship can be further enhanced or diminished by the habitat area that salmon occupy for spawning.

In the Great Lakes, contaminant biotransport varies among Lakes Michigan, Huron, and Superior with Lake Michigan exhibiting the greatest, Lake Huron exhibiting intermediate, and Lake Superior exhibiting minimal biotransport of PCBs (Figure 2A; Janetski et al., 2012; Gerig et al., 2016). This gradient reflects the contaminant levels of spawners and their densities. Contaminant biotransport in Lake Michigan is enhanced by highly contaminated Chinook salmon (Oncorhynchus tshawytscha) spawning at high densities, while Lake Superior tributaries receive comparatively small runs of lesser contaminated coho (Oncorhynchus kisutch). This pattern suggests that the salmon biotransport of POPs to streams is influenced by species- and basin-specific factors. For instance, Chinook salmon have higher trophic positions, reach larger sizes, and bioaccumulate greater contaminant burdens than coho, making them a more effective biovector (Gerig et al., 2016). In addition, Lake Michigan has (1) a thermal regime and prey fish populations that supports larger salmon biomass, both in terms of overall abundance and fish size, than Lake Superior (Dettmers et al., 2012; Bunnell et al., 2014), and (2) higher levels of current and historic contamination than Lake Superior (Hornbuckle et al., 2006). Salmon biotransport of $\mathrm{Hg}$ is also observed in the 

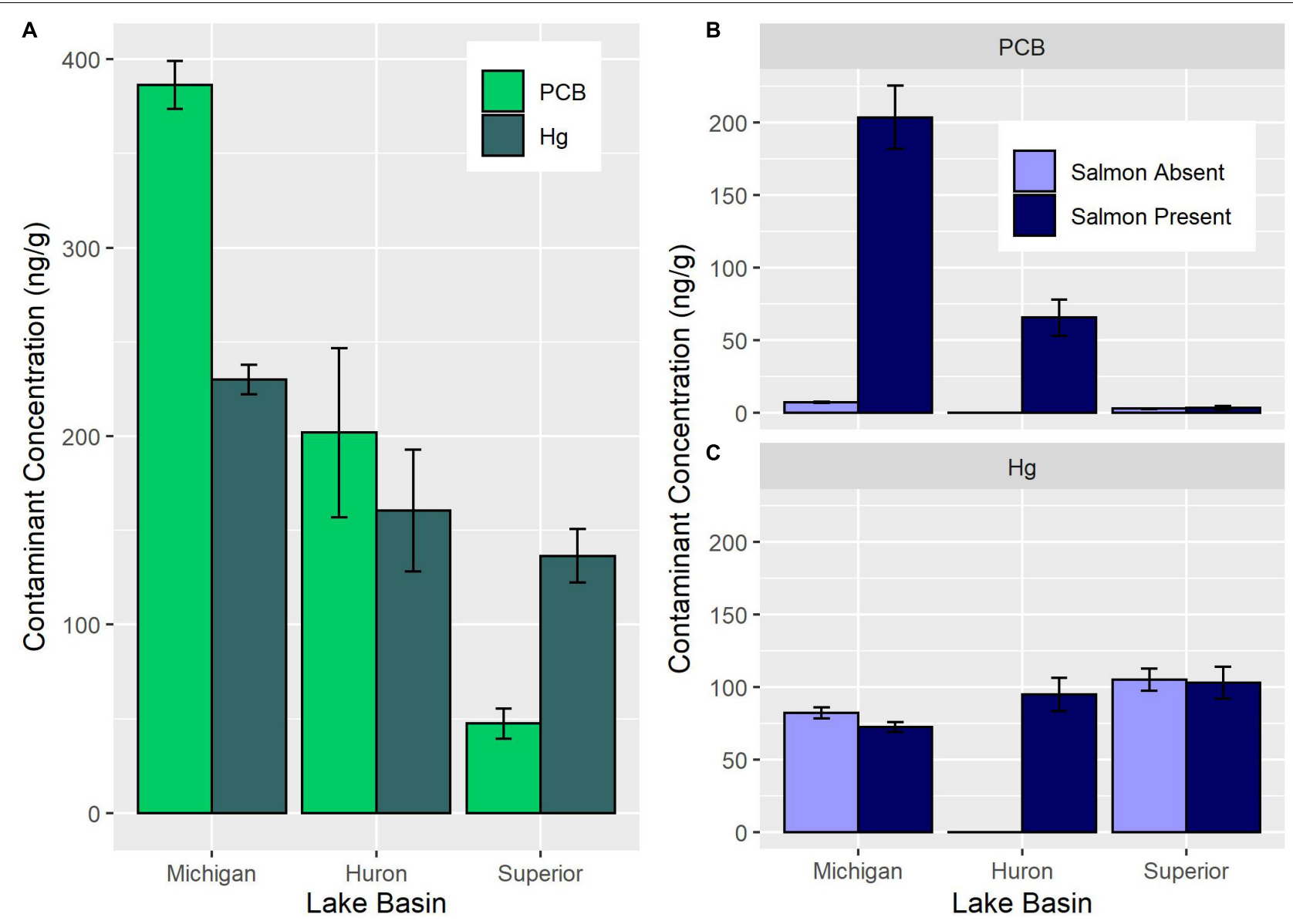

FIGURE 2 | Spawning Pacific salmon exhibit basin-specific differences in PCB and Hg concentrations across Lakes Michigan, Huron, and Superior (A). Stream-resident fish exhibit PCB concentrations that differ among lake basins and between locations open to Pacific salmon (B). Stream-resident fish exhibit Hg concentrations that differ among lake basins but not with the presence of Pacific salmon (C). Note the magnitude of difference is much more pronounced for PCB than $\mathrm{Hg}$. No stream-resident fish were collected from salmon absent Lake Huron tributaries. All concentrations expressed as ng/g wet weight. Data source: Gerig, 2017.

Great Lakes (Sarica et al., 2004; Gerig et al., 2018). The magnitude of difference in salmon $\mathrm{Hg}$ concentrations among Upper Great Lakes basin is smaller than POPs due to smaller differences in atmospheric deposition among the Upper Lakes (Risch et al., 2017). However, similar to the POP pattern, Hg concentrations are highest in Lake Michigan and lowest in Lake Superior (Gerig, 2017). Understanding factors controlling the transport of contaminants to tributaries is the first requirement for understanding how salmon alter bioaccumulation in tributaries.

Contaminants accumulate at different rates in fish tissues based upon the biochemical properties (e.g., protein or lipid content) of the tissue (e.g., muscle, gametes). As such, differential bioaccumulation between tissues can be used to determine the trophic pathway responsible for increased resident fish bioaccumulation. Salmon deposit eggs and carcasses in streams during spawning. Salmon eggs have higher PCB concentrations than muscle and very low concentrations of $\mathrm{Hg}$ (Gerig et al., 2018). PCBs are lipophilic and accumulate readily into fatrich tissues, such as fish eggs (Blais et al., 2007; Murphy et al., 2012). In contrast, $\mathrm{Hg}$ binds to proteins in muscle tissue
(Kuwabara et al., 2007), which is largely absent from eggs and therefore limits $\mathrm{Hg}$ accumulation. Thus, consideration of PCB and $\mathrm{Hg}$ concentrations together is an effective tool to identify how salmon influence stream-resident fish bioaccumulation.

Bioaccumulation of biotransported contaminants by streamresident fish is dependent upon whether POPs or $\mathrm{Hg}$ are considered. Stream-resident fish including native brook and introduced brown trout exposed to salmon runs exhibit a 24-fold higher PCB concentration than fish from non-salmon reaches (Figure 2B; Gerig et al., 2018). Moreover, PCB concentrations in stream-resident fish increase non-linearly with the quantity of PCB delivered by salmon (Figure 3; Gerig et al., 2018). Similarly, concentrations of other POPs, like DDE and PBDE, in streamresident fish also increase with the increased flux of salmon derived contaminants (Janetski et al., 2012). However, DDE and PBDE concentrations in salmon spawners are low compared to PCBs, reflecting lower environmental concentrations (Janetski et al., 2012; Murphy et al., 2012). Together, these findings suggest that other POPs such as Mirex, Dieldrin, and Chlordane with similar properties to PCBs are subject to biotransport 


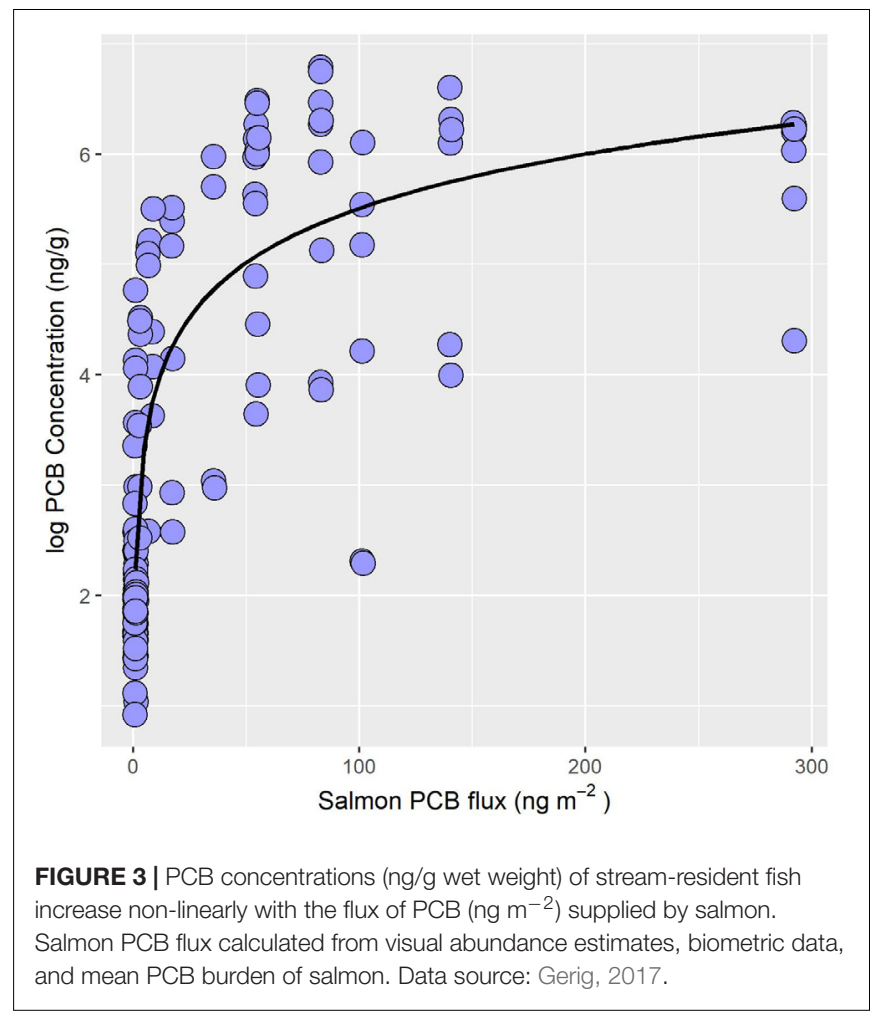

by Pacific salmon (e.g., O’Toole et al., 2006). However, the extent of biotransport reflects the relative concentration in the environment.

Mercury is recognized as another important contaminant in the Great Lakes region. Despite evidence of $\mathrm{Hg}$ biotransport by salmon (Sarica et al., 2004; Gerig et al., 2018), streamresident fish in the Great Lakes have reduced or negligible differences in $\mathrm{Hg}$ between locations with and without salmon (Figure 2C; Gerig et al., 2018). Moreover, Hg in stream-resident fish decline as $\mathrm{Hg}$ supplied by salmon and stream-resident fish size increases (Gerig et al., 2018). In contrast, a mesocosm experiment that measured the effect of carcass consumption on $\mathrm{Hg}$ bioaccumulation determined that brook and brown trout $\mathrm{Hg}$ increased with increased salmon consumption (Gerig et al., 2017). However, similar to field studies from the Great Lakes, Dolly Varden char (Salvelinus malma) in Alaska have lower $\mathrm{Hg}$ concentrations as the abundance of spawning salmon increases (Cyr et al., 2016). If salmon-derived contaminants were accumulated primarily through carcass consumption, then data from observational studies should demonstrate a paired increase in both $\mathrm{PCB}$ and $\mathrm{Hg}$ concentrations much like what has been observed in Grizzly Bears (Christensen et al., 2005). These results suggest that understanding the trophic ecology of the receiving food web is essential to understanding how biotransported contaminants are bioaccumulated.

Diet and ration size interact to influence the bioaccumulation of salmon derived contaminants. Stream-resident fish subjected to salmon in the Great Lakes shift their diet to consume energydense salmon eggs during fall salmon runs (Ivan et al., 2011; Gerig et al., 2019). Stream-resident fish have been found to

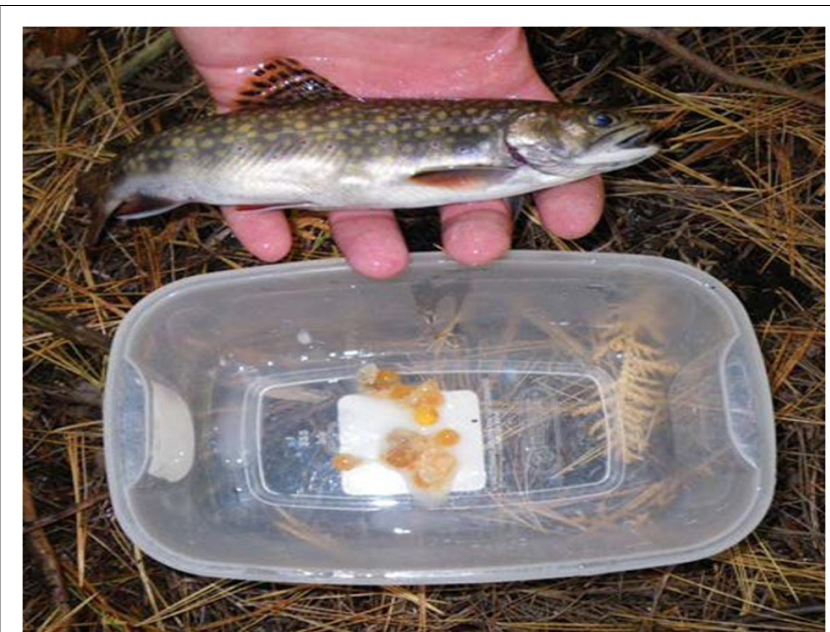

FIGURE 4 | A native brook trout that had gorged on salmon eggs in a northern Lake Michigan tributary. Photo credit: David Janetski.

gorge on salmon eggs with ration size increasing 14-fold from pre-salmon run levels. When salmon are present, eggs account for $\sim 70 \%$ of their diet (Figure 4; Gerig et al., 2019). However, widespread variability in the degree of egg consumption (Gerig et al., 2019), both in space and time, suggests that dietary plasticity among individuals can enhance exposure to POPs. Moreover, differential bioaccumulation of POPs and $\mathrm{Hg}$ by stream-resident fish may be modulated by variability in egg consumption. A simulation model parametrized using field data demonstrated a trade-off between PCB and Hg bioaccumulation that was mediated by the degree of egg consumption (Gerig et al., 2019). Increased egg consumption resulted in increased streamresident fish growth and PCB concentration while leading to a simultaneous decline in $\mathrm{Hg}$ concentration attributed both to the low mercury content of eggs and somatic growth dilution (Gerig et al., 2019). Previous research in locations lacking biovectors has found that stream-resident fish PCB and Hg concentrations vary with physical and chemical factors related to water chemistry and land cover (King et al., 2004). However, salmon deliver such a large contaminant flux that other factors that would otherwise modulate stream-resident fish bioaccumulation are overshadowed. The stronger influence of biological over physicochemical factors parallels other research on the ecological effects of salmon spawners where the stable isotope ratio of resident fish was more strongly influenced by the salmon run size than by instream or landscape-level variables (Reisinger et al., 2013; Swain et al., 2014). This highlights the strong influence that salmon have on ecosystems as ecosystem engineers as well as provision of resource subsidies (Schindler et al., 2003).

Salmon release considerable quantities of POPs and $\mathrm{Hg}$ through carcass deposition that could influence bioaccumulation in other food web components. A large portion of salmon-derived POPs and $\mathrm{Hg}$ is transported downstream following carcass decomposition (Sarica et al., 2004; O'Toole et al., 2006). O’Toole et al. (2006) found that semi-permeable membrane devices accumulated more POPs when spawning and decomposing 
salmon were present. In addition, Sarica et al. (2004) observed increased aqueous concentrations of total and methylated $\mathrm{Hg}$ during carcass decomposition. While localized salmon spawning can increase the aqueous concentration of POPs and $\mathrm{Hg}$, neither study determined whether increased aqueous concentrations correlated with increased bioconcentration or food web bioaccumulation. Sarica et al. (2004) also found a significant increase in $\mathrm{Hg}$ concentrations in for aquatic invertebrates from scavenging or collector-gathering feeding guilds. Limited data exists on the effect of salmon on stream invertebrate POP concentrations but we would anticipate invertebrates to respond, similarly, to Sarica et al. (2004). In contrast, the gut microbiome of stream invertebrates from a wide range of feeding guilds did not change as a result of an experimental salmon carcass introduction suggesting minimal use of this resource (Larson et al., 2019). In addition, a previous study noted that black bears (Ursus americanus) translocated a significant quantity of $\mathrm{Hg}$ to the riparian zone of the Credit River in the Lake Ontario watershed significantly diminishing the quantity of $\mathrm{Hg}$ available for downstream transport (Sarica et al., 2004). POPs were not measured in this study, but we would expect for POPs transported to riparian zone by bears. Observations of carcass translocation to the riparian corridor has not been noted in the Upper Great Lakes (Janetski et al., 2012; Gerig et al., 2018) but should be explored in the future.

\section{FUTURE DIRECTIONS AND MANAGEMENT}

Past research has focused narrowly on semelparous Pacific salmon when assessing migratory fish contaminant biotransport (Gregory-Eaves et al., 2007; Janetski et al., 2012; Gerig et al., 2018). However, many different migratory fish have the potential to transport contaminants. Previous reviews suggest iteroparous fish, such as steelhead or suckers, represent a diminished risk for contaminant biotransport because they only deposit gametes (Blais et al., 2007; Kallenborn and Blais, 2015). However, eggs represent a POP-rich food resource that fish readily gorge upon when available (Gerig et al., 2019). Different migratory fish have different spawning strategies, such as broadcast vs. nest spawning, which may impact the availability of eggs for consumption. In addition, fish eggs, even within the Oncorhynchus genus, exhibit differential provisioning, leading to variability in size and lipid content thereby influencing POP concentrations (Quinn, 2018). Determining what species of migratory fish function as significant biovectors will require a detailed trait-based analysis (cf. Schiesari et al., 2018). For example, in the Great Lakes over 50 fish species have been identified as having a migratory or partially migratory life history (Lane et al., 1996). The fish species associated with Great Lakes tributaries differs markedly with respect to contaminant burden, abundance, fecundity, spawning mode, run timing, and swimming ability with consequences for their individual capacity to accumulate, transport, and deliver contaminants. Identifying variables that enhance or diminish contaminant biotransport is an important step to managing inputs of biotransported contaminants.
Biotransported contaminants present a challenge from a management perspective because they defy the conventional paradigm of pollution flowing from upstream to downstream. Illustrating this challenge, biotransport is seldom included in risk assessments used to construct fish consumption advisories. Based upon an analysis of data presented in Gerig (2017) from the Lake Michigan and Huron Basin, 50\% of stream-resident trout from streams open to salmon had PCB concentrations that exceeded the no fish consumption guideline for cancer causing and 25\% exceeded non-cancer causing endpoints (Figure 5; US Environmental Protection Agency, 2000). This finding points to an opportunity where existing contaminant databases could be leveraged to identify "hot-spots" of biotransport that could subsequently be targeted for consumption advisories and public outreach (Gerig et al., 2018). However, effective use of that information will require better understanding of the biology of contaminant transport, especially in the context of local chemical and physical conditions, which are strongly driven by human activities.

One important factor in the Great Lakes region is the large number of tributary dams that impact ecosystem connectivity. Environmental contaminants (Murphy et al., 2012) interact with aging dam infrastructure (Stanley and Doyle, 2003) to create ecological stressors that impact the fisheries and watersheds. Removal of obsolete dams can improve lotic function by increasing sediment transport, restoring natural thermal and flow regimes, and extending migration corridors for fish

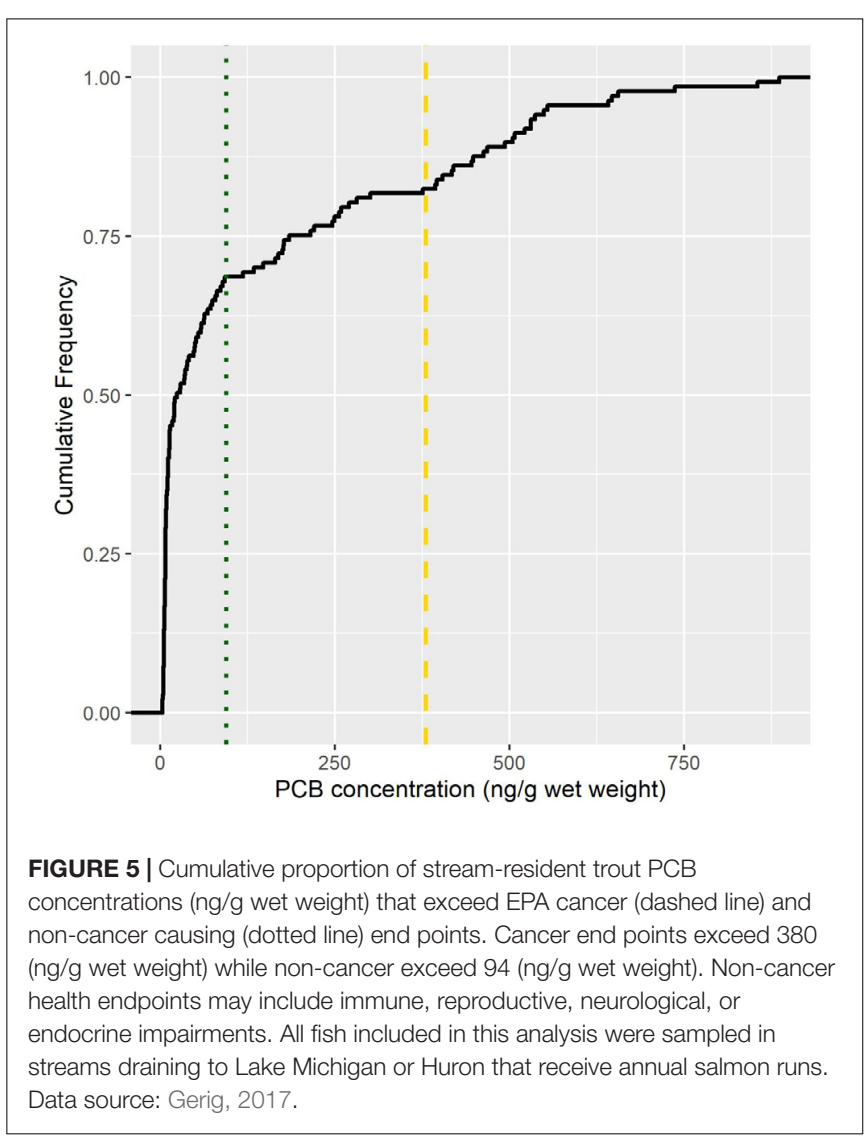


(Poff et al., 1997). However, dam removal may also increase the likelihood of invasive species colonization and contaminant biotransport by migratory fish (Figure 1; McLaughlin et al., 2013; Gerig et al., 2019). Although dam removal can provide ecological benefits, careful consideration and prioritization should be employed to minimize other impacts (Rahel, 2013), including the risk of contaminant transport (Janetski et al., 2012). Future management could involve developing a decisionmaking process that simultaneously minimizes biotransport and non-native species dispersal while restoring connectivity for native species. For example, managers could identify species likely to have the most impact in terms of contaminant biotransport and establish seasonal barriers that would selectively prevent those species from migrating upstream; seasonal barriers have successfully been implemented in the Great Lakes to limit expansion of Sea Lamprey (Petromyzon marinus) into tributaries (Lavis et al., 2003). Selective barriers may be a feasible management option for species that migrate with a predictable phenology if ecosystem and human health impairments are apparent. One key tool in development of that process will be to establish a decision-making framework for use by managers to address costs and benefits of such actions.

Recent modeling efforts have demonstrated the ability to identify mechanisms controlling contaminant biotransport (McGill et al., 2017; Gerig et al., 2019). However, these assessments have been restricted to POPs such as PCBs, which are declining and currently banned from production (Murphy et al., 2012). In contrast, more than 1,000 chemicals have been identified as having the ability to bioaccumulate with one-third exhibiting potentially toxic effects on aquatic biota, wildlife, and human health (Murphy et al., 2012; Walters et al., 2016). Moreover, many thousands of chemicals are developed every year with only minimal consideration of their environmental impact (Walters et al., 2016). Expansion of recent models could be leveraged to determine the risk of biotransport of emerging contaminants that are hydrophobic, resistant to degradation, and present a clear bioaccumulation risk. This effort may be a particularly useful application of models because adequately screening all potential chemicals that pose regional and global risks remains challenging (Walters et al., 2016).

This mini-review synthesizes our current understanding of the mechanisms and variation surrounding the process

\section{REFERENCES}

Assessment, M. E. (2005). Ecosystems and Human Well-Being, Vol. 5. Washington, DC: Island press.

Bauer, S., and Hoye, B. J. (2014). Migratory animals couple biodiversity and ecosystem functioning worldwide. Science 344:1242552. doi: 10.1126/science. 1242552

Blais, J. M. (2005). Biogeochemistry of persistent bioaccumulative toxicants: processes affecting the transport of contaminants to remote areas. Can. J. Fish. Aquat. Sci. 62, 236-243. doi: 10.1139/f04-226

Blais, J. M., Macdonald, R. W., Mackay, D., Webster, E., Harvey, C., and Smol, J. P. (2007). Biologically mediated transport of contaminants to aquatic systems. Environ. Sci. Technol. 41, 1075-1084. doi: 10.1021/es061314a

Bunnell, D. B., Barbiero, R. P., Ludsin, S. A., Madenjian, C. P., Warren, G. J., Dolan, D. M., et al. (2014). Changing ecosystem dynamics in the laurentian of contaminant biotransport by Pacific salmon, an issue of high importance given widespread introductions of salmon on multiple continents. Overall, research at differing scales and levels of control has demonstrated that salmon can have a marked impact on stream-resident fish contaminant burdens. However, salmon do not uniformly impact the stream-resident fish community and the magnitude of their effect appears tightly linked to the biological context related to the specific contaminant, species identity, and trophic pathway to contamination, which interact to determine the magnitude of salmon biotransport and uptake. Consequently, consideration of the recipient food web and route of exposure is critical to understanding the fate of biotransported contaminants in ecosystems.

\section{AUTHOR CONTRIBUTIONS}

BG, DJ, DC, and GL had equal contributions to the development, writing, and revision of this manuscript. All authors contributed to the article and approved the submitted version.

\section{FUNDING}

The Great Lakes Fishery Trust (Projects 2007.857 and 2012.1244) provided funding that supported the development of this manuscript. BG was also supported through an EPA STAR Fellowship (\#F13F11071).

\section{ACKNOWLEDGMENTS}

We thank Rick Rediske, James O'Keefe, and Ashley Moerke for conversations and insight regarding contaminant bioaccumulation and contaminant biotransport in the Great Lakes. We thank Mike Brueseke, Sean Cullen, Nathan Herman, Lillian McGill, and Nick Weber for providing extensive field and lab support. The Center for Environmental Science and Technology at the University of Notre Dame provided technical support for this research.

great lakes: bottom-up and top-down regulation. Bioscience 64, 26-39. doi: 10.1093/biosci/bit001

Christensen, J. R., MacDuffee, M., MacDonald, R. W., Whiticar, M., and Ross, P. S. (2005). Persistent organic pollutants in British Columbia grizzly bears: consequence of divergent diet. Environ. Sci. Technol. 39, 6952-6960. doi: 10. 1021/es050749f

Clements, W. H., Hickey, C. W., and Kidd, K. A. (2012). How do aquatic communities respond to contaminants? It depends on the ecological context. Environ. Toxicol. Chem. 31, 1932-1940. doi: 10.1002/etc. 1937

Crawford, S. (2001). Salmonine Introductions to The Laurentian Great Lakes: An Historical Review and Evaluation of Ecological Effects. Ottawa: NRC Research Press.

Cyr, A., Sergeant, C. J., Lopez, J. A., and O’Hara, T. (2016). Assessing the influence of migration barriers and feeding ecology on total mercury concentrations in 
Dolly Varden (Salvelinus malma) from a glaciated and non-glaciated stream. Sci. Total Environ. 580, 710-718. doi: 10.1016/j.scitotenv.2016.12.017

Dettmers, J. M., Goddard, C. I., and Smith, K. D. (2012). Management of alewife using Pacific salmon in the Great Lakes: whether to manage for economics or the ecosystem? Fisheries 37, 495-501. doi: 10.1080/03632415.2012.731875

Gerig, B. S. (2017). Controls of Contaminant Biotransport by Pacific Salmon to Great Lakes Tributaries. Available at: https://search.proquest.com/ docview/2171772692/fulltextPDF/128E53B2306D4B07PQ/1 ?accountid=12598 (accessed April 9, 2019).

Gerig, B. S., Chaloner, D. T., Janetski, D. J., Moerke, A. H., Rediske, R. R., O’Keefe, J. P., et al. (2018). Environmental context and contaminant biotransport by Pacific salmon interact to mediate the bioaccumulation of contaminants by stream-resident fish. J. Appl. Ecol. 55, 1846-1859. doi: 10.1111/1365-2664. 13123

Gerig, B. S., Chaloner, D. T., Janetski, D. J., Rediske, R. R., O’Keefe, J. P., Moerke, A. H., et al. (2016). Congener patterns of persistent organic pollutants establish the extent of contaminant biotransport by Pacific salmon in the Great Lakes. Environ. Sci. Technol. 50, 554-563. doi: 10.1021/acs.est.5b05091

Gerig, B. S., Hermann, N. T., Chaloner, D. T., and Lamberti, G. A. (2019). Using a dynamic bioenergetics-bioaccumulation model to understand mechanisms of uptake and bioaccumulation of salmon-derived contaminants by streamresident fish. Sci. Total Environ. 652, 633-642. doi: 10.1016/j.scitotenv.2018. 10.149

Gerig, B. S., Weber, D. N., Chaloner, D. T., McGill, L. M., and Lamberti, G. A. (2017). Interactive effects of introduced Pacific salmon and brown trout on native brook trout: an experimental and modeling approach. Can. J. Fish. Aquat. Sci. 75, 538-548. doi: 10.1139/cjfas-2016-0502

Gregory-Eaves, I., Demers, M. J., Kimpe, L., Krümmel, E. M., Macdonald, R. W., Finney, B. P., et al. (2007). Tracing salmon-derived nutrients and contaminants in freshwater food webs across a pronounced spawner density gradient. Environ. Toxicol. Chem. 26, 1100-1108.

Hornbuckle, K. C., Carlson, D. L., Swackhamer, D. L., Baker, J. E., and Eisenreich, S. J. (2006). Polychlorinated biphenyls in the Great Lakes. Hdb. Env. Chem. 5, 13-70. doi: 10.1007/698_5_039

Ivan, L. N., Rutherford, E. S., and Johengen, T. H. (2011). Impacts of adfluvial fish on the ecology of two great Lakes tributaries. Trans. Am. Fish. Soc. 140, 1670-1682. doi: 10.1080/00028487.2011.642233

Janetski, D. J., Chaloner, D. T., Moerke, A. H., Rediske, R. R., O'Keefe, J. P., and Lamberti, G. A. (2012). Resident fishes display elevated organic pollutants in salmon spawning streams of the Great Lakes. Environ. Sci. Technol. 46, 8035-8043. doi: $10.1021 /$ es301864k

Kallenborn, R., and Blais, J. M. (2015). "Tracking contaminant transport from biovectors," in Environmental Contaminants, eds M. R. Rosen, and J. P. Smol (Dordrecht: Springer).

King, R. S., Beaman, J. R., Whigham, D. F., Hines, A. H., Baker, M. E., and Weller, D. E. (2004). Watershed land use is strongly linked to PCBs in white perch in Chesapeake Bay subestuaries. Environ. Sci. Technol. 38, 6546-6552. doi: $10.1021 / \mathrm{es} 049059 \mathrm{~m}$

Krümmel, E. M., Macdonald, R. W., Kimpe, L. E., Gregory-Eaves, I., Demers, M. J., Smol, J. P., et al. (2003). Aquatic ecology: delivery of pollutants by spawning salmon. Nature 425, 255-256.

Kuwabara, J. S., Arai, Y., Topping, B. R., Pickering, I. J., and George, G. N. (2007). Mercury speciation in piscivorous fish from mining-impacted reservoirs. Environ. Sci. Technol. 41, 2745-2749. doi: 10.1021/es0628856

Lamberti, G. A., Chaloner, D. T., and Hershey, A. E. (2010). Linkages among aquatic ecosystems. J. N. Am. Benthol. Soc. 29, 245-263. doi: 10.1899/08-166.1

Lane, J. A., Portt, C. B., and Minns, C. K. (1996). Adult Habitat Characteristics of Great Lakes Fishes. Ottawa: Fisheries and Oceans Canada.

Larson, C. E., Pechal, J. L., Gerig, B. S., Chaloner, D. T., Lamberti, G. A., and Benbow, M. E. (2019). Microbial community response to a novel salmon resource subsidy. Front. Ecol. Evol. 7:505. doi: 10.3389/fevo.2019.00505

Lavis, D. S., Hallett, A., Koon, E. M., and McAuley, T. C. (2003). History of and advances in barriers as an alternative method to suppress sea lampreys in the Great Lakes. J. Great Lakes Res. 29, 362-372. doi: 10.1016/s0380-1330(03) 70500-0

Mackay, D., and Fraser, A. (2000). Bioaccumulation of persistent organic chemicals: mechanisms and models. Environ. Pollut. 110, 375-391. doi: 10. 1016/s0269-7491(00)00162-7
McGill, L. M., Gerig, B. S., Chaloner, D. T., and Lamberti, G. A. (2017). An ecosystem model for evaluating the effects of introduced Pacific salmon on contaminant burdens of stream-resident fish. Ecol. Model. 355, 39-48. doi: 10.1016/j.ecolmodel.2017.03.027

McLaughlin, R. L., Smyth, E. R. B., Castro-Santos, T., Jones, M. L., Koops, M. A., Pratt, T. C., et al. (2013). Unintended consequences and trade-offs of fish passage. Fish Fish. 14, 580-604. doi: 10.1111/faf.12003

Michuelleti, N., Blais, J. M., Mallory, M. L., Brash, J., Thienpont, J., Kimpe, L. E., et al. (2010). Trophic position influences the efficacy of seabirds as metal biovectors. Proc. Natl. Acad. Sci. U.S.A. 107, 10543-10548. doi: 10.1073/pnas. 1001333107

Murphy, C. A., Bhavasar, S. P., and Gandhi, N. (2012). "Contaminants in Great Lakes fish: historic, current, and emerging contaminants," in Great Lakes Fisheries Policy and Management: A Binational Perspective, eds W. W. Taylor, A. J. Lynch, and N. J. Leonard (Lansing, MI: Michigan State University Press).

O’Toole, S., Metcalfe, C., Craine, I., and Gross, M. (2006). Release of persistent organic contaminants from carcasses of Lake Ontario Chinook salmon (Oncorhynchus tshawytscha). Environ. Pollut. 140, 102-113. doi: 10.1016/j. envpol.2005.06.019

Poff, N. L., Allan, J. D., Bain, M. B., Karr, J. R., Prestegaard, K. L., Richter, B. D., et al. (1997). The natural flow regime: a paradigm for river conservation and restoration. Bioscience 47, 769-784.

Polis, G. A., Power, M. E., and Huxel, G. R. (2004). Food Webs at The Landscape Level. Chicago, IL: University of Chicago Press.

Quinn, T. P. (2018). The Behavior and Ecology of Pacific Salmon and Trout. Seattle, WA: University of Washington Press.

Rahel, F. J. (2013). Intentional fragmentation as a management strategy in aquatic systems. BioScience 63, 362-372. doi: 10.1525/bio.2013.63.5.9

Reisinger, A. J., Chaloner, D. T., Ruegg, J., Tiegs, S., and Lamberti, G. A. (2013). Effects of spawning Pacific salmon on the isotopic composition of biota differ among southeast Alaska streams. Freshw. Biol. 58, 938-950. doi: 10.1111/fwb. 12098

Risch, M. R., DeWild, J. F., Gay, D. A., Zhang, L., Boyer, E. W., and Krabbenhoft, D. P. (2017). Atmospheric mercury deposition to forests in the eastern USA. Environ. Pollut. 228, 8-18. doi: 10.1016/j.envpol.2017.05.004

Sarica, J., Amyot, M., Hare, L., Doyon, M. R., and Stanfield, L. W. (2004). Salmonderived mercury and nutrients in a Lake Ontario spawning stream. Limnol. Oceanogr. 49, 891-899. doi: 10.4319/lo.2004.49.4.0891

Schiesari, L., Leibold, M. A., and Burton, G. A. Jr. (2018). Metacommunities, metaecosystems and the environmental fate of chemical contaminants. J. Appl. Ecol. 55, 1553-1563. doi: 10.1111/1365-2664.13054

Schindler, D. E., Scheuerell, M. D., Moore, J. W., Gende, S. M., Francis, T. B., and Palen, W. J. (2003). Pacific salmon and the ecology of coastal ecosystems. Front. Ecol. Environ. 1, 31-37. doi: 10.1890/1540-92952003001[0031:PSATEO] 2.0.CO;2

Stanley, E. H., and Doyle, M. W. (2003). Trading off: the ecological effects of dam removal. Front. Ecol. Environ. 1:15-22. doi: 10.2307/3867960

Swain, N., Swain, M., Hocking, J., Harding, J., Reynolds, J., and Richardson, J. D. (2014). Effects of salmon on the diet and condition of stream-resident sculpins. Can. J. Fish. Aquat. Sci. 71, 521-532. doi: 10.1139/cjfas-2013-0159

US Environmental Protection Agency (2000). "Guidance for Assessing Chemical Contaminant Data for Use in Fish Advisories." Risk Assessment and Fish Consumption Limits, Third Edn. Washington, DC: US Environmental Protection Agency.

Walters, D. M., Jardine, T. D., Cade, B. S., Kidd, K. A., Muir, D. C. G., and LeipzigScott, P. (2016). Trophic magnification of organic chemicals: a global synthesis. Environ. Sci. Technol. 50, 4650-4658. doi: 10.1021/acs.est.6b00201

Conflict of Interest: The authors declare that the research was conducted in the absence of any commercial or financial relationships that could be construed as a potential conflict of interest.

Copyright $\odot 2020$ Gerig, Janetski, Chaloner and Lamberti. This is an open-access article distributed under the terms of the Creative Commons Attribution License (CC BY). The use, distribution or reproduction in other forums is permitted, provided the original author(s) and the copyright owner(s) are credited and that the original publication in this journal is cited, in accordance with accepted academic practice. No use, distribution or reproduction is permitted which does not comply with these terms. 